\title{
BACTERIOLOGICAL INVESTIGATION OF AIR DURING AN EPIDEMIC OF HAEMOLYTIC STREPTOCOCCAL THROAT INFECTION
}

\author{
PART I
}

\author{
BY \\ *C. A. GREEN, S. W. CHALLINOR \\ and \\ J. P. DUGUID
}

From the Royal Naval Medical School, and Bacteriology Department, Edinburgh University

\section{Introduction}

Critical reviews concerning the problems of airborne infection have been prepared by Mackie, T. J. (1942), by Buchbinder, L. (1942) and, subsequent to the completion of the work described in this paper, by Mudd (1944) and by Mitman (1945). It is apparent that the respiratory infections are among the most important causes of ill health. In particular the relationship between nasopharyngeal infection by haemolytic streptococci and acute rheumatism has been stressed (Glover, 1930; Coburn, 1931; Collis, 1931; Green, 1942). It is uncertain to what extent respiratory tract infections are spread by air-carriage of infected droplet-nuclei or infected dust-particles. Many laboratory studies of air infection by droplet-spray, and by the raising of infected dust, have been published in recent years, but such studies do not give an account of the extent to which air-infection with pathogenic organisms occurs naturally in the presence of respiratory infection.

The work described below consisted essentially of an investigation of the bacterial flora of the air of the various dwelling places of a semi-closed community of youths, aged 15 to 19 , during an epidemic of haemolytic streptococcal throat infections during the latter part of 1942.

Detailed observations of the bacterial content, especially of streptococci, of the air of a dormitory, the cinema hall, a recreation room, and a schoolroom, were made at the height of the epidemic and it was hoped that such data would indicate which parts of the daily routine of the occupants of the institution (i.e. sleeping, recreation, work, etc.) exposed them to the greatest danger of airborne infection. In addition to the bacteriological observations made under normal living conditions, observations were also made under special conditions, such as in the immediate vicinity of known sources of infection; these latter observations are described in Part II of this paper. It was hoped that the collected results of these experiments would show what degree of air-infections with the specific pathogenic organisms occurred under epidemic conditions; and what sources and mechanisms were responsible for the bulk of such infection.

Measurements of the bacterial content of the air were made with the slit sampler as designed by Bourdillon, Lidwell, and Thomas (1941) which involves suction of a measured volume of air through a narrow slit on to a revolving plate of medium placed very close $(2 \mathrm{~mm}$.- -we used a slitplate distance of $3 \mathrm{~mm}$.) to the slit. This method yields results of considerable accuracy, and has been employed by Thomas and van den Ende (1941), Bourdillon, Lidwell, and Lovelock (1942), Challinor (1943), and by others for bacteriological observations of the air of occupied premises.

In order to facilitate identification and counting of the streptococci, a selective medium-namely, blood agar incorporating crystal violet in a concentration of 1 part in 1 million, as used by Challinor (1943), was employed. Ordinary blood-agar plates were used for observations on the total number of bacteria-carrying particles present in the air.

\section{Epidemiological Background}

The community of some 765 youths was housed in a permanent camp of single-storied buildings, designed for the specific purpose for which they were being used and placed on a low hill-top half a mile $(0.8 \mathrm{~km}$.) from the bank of an estuary. The institution was complete with dormitories, mess rooms, kitchens, workshops, schoolrooms, swimming baths, cinema, recreation rooms, and gymnasium. The nearest village was one mile $(1.6 \mathrm{~km}$.) away and some four miles $(6.4 \mathrm{~km}$.) off was a town of considerable size. The boys were allowed to visit both places in their leisure time but relatively few took the opportunity.

The dormitories were arranged in three separate blocks, A, B, and C, the dormitories in each block being linked together by covered corridors. These three blocks were identical in construction and 
ventilation. Each dormitory measured $80 \mathrm{ft} . \times$ $20 \mathrm{ft} . \times 10 \mathrm{ft} .(24 \mathrm{~m} . \times 6 \mathrm{~m} . \times 3 \mathrm{~m}$. $)$ and was occupied on an average by 33 boys. Apart from clothes lockers and single beds, no other furniture was present and adequate ventilation was secured by means of windows down each side of the buildings. The wooden floors were covered with polished linoleum, and the corners between floor and skirting were rounded to aid cleaning. Dormitories were swept daily; the sweepings invariably containing a considerable amount of fibre from mattresses, blankets, towels, and clothing.

The boy population joined the establishment in groups of 50 to 70 at intervals of four to six months and remained under instruction for three and a half years. On entry, a new group occupied the two dormitories at one end of block $C$ and passed in sequence through the blocks $\mathrm{C}, \mathrm{B}$, and A during their stay at the institution. If a group became reduced in size and could not occupy all the beds in two dormitories, the vacancies were filled by members of another group.

The health of the community was very good during the summer months of 1942, but about the middle of October, tonsillitis became prevalent and was accompanied by the appearance of scarlatina, as shown in Table 1. A rise in the incidence of common colds preceded the tonsillitis wave by some weeks. Clinically, cases of scarlatina were of

TABLE 1

RISE OF EPIDEMIC BEFORE START OF INVESTIGATION

\begin{tabular}{|c|c|c|c|c|}
\hline \multirow{2}{*}{$\begin{array}{c}1942 \\
\text { period }\end{array}$} & & \multicolumn{3}{|c|}{ Number of fresh cases } \\
\hline & & Tonsillitis & $\begin{array}{c}\text { Common } \\
\text { cold }\end{array}$ & Scarlatina \\
\hline 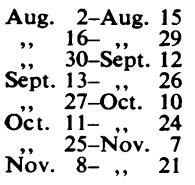 & $\begin{array}{l}\cdots \\
\cdots \\
\cdots \\
\cdots \\
\cdots \\
\cdots\end{array}$ & $\begin{array}{r}2 \\
4 \\
2 \\
6 \\
3 \\
13 \\
19 \\
26\end{array}$ & $\begin{array}{r}2 \\
2 \\
3 \\
10 \\
11 \\
16 \\
14 \\
21\end{array}$ & $\begin{array}{r}0 \\
0 \\
0 \\
0 \\
0 \\
4 \\
12 \\
13\end{array}$ \\
\hline
\end{tabular}

mild character without serious complications apart from otitis, which appeared in a number during hospitalization. The investigations detailed below were made during the period 13 to 29 Nov. 1942, when the epidemic was in full swing. Only one case of subacute rheumatism was recorded in the community during the following two months. The

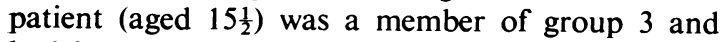
had been hospitalized with scarlet fever during the epidemic. Neither before nor at the time of the institutional outbreak was there any indication of an epidemic wave in the adjacent village and town, although a small number of outside contact cases appeared in households visited by the youths.

In such a community there was considerable contact in workshops, schoolroom, and recreation room between members of the three dormitory blocks, although less than that between members of different dormitories in the same blocks. Table 2 shows clearly how the epidemic was confined largely to block $\mathrm{C}$, which was occupied by juniors both in actual and in service age.

TABLE 2

\section{DORMITORY DISTRIBUTION OF EPIDEMIC CASES}

\begin{tabular}{|c|c|c|c|c|c|c|c|}
\hline \multirow{2}{*}{$\begin{array}{l}\text { Dormi- } \\
\text { tory } \\
\text { block }\end{array}$} & \multirow{2}{*}{ Group } & \multirow{2}{*}{$\begin{array}{c}\text { Average } \\
\text { age }\end{array}$} & \multirow{2}{*}{$\begin{array}{l}\text { Num- } \\
\text { ber in } \\
\text { group }\end{array}$} & \multirow{2}{*}{$\begin{array}{l}\text { Estab. } \\
\text { age in } \\
\text { mths.* }\end{array}$} & \multicolumn{3}{|c|}{$\begin{array}{l}\text { Number of cases } \\
\text { during period Aug. 2- } \\
\text { Nov. 21 }\end{array}$} \\
\hline & & & & & $\begin{array}{l}\text { Tonsil- } \\
\text { litis } \\
\text { cold }\end{array}$ & $\begin{array}{l}\text { Com- } \\
\text { mon } \\
\text { cold }\end{array}$ & $\begin{array}{l}\text { Scarlet } \\
\text { fever }\end{array}$ \\
\hline \multirow[t]{2}{*}{ C } & $\begin{array}{l}1 \\
2 \\
3 \\
4 \\
5\end{array}$ & $\begin{array}{l}15 \frac{1}{2} \\
15 \frac{1}{2} \\
15 \frac{1}{2} \\
16 \\
16\end{array}$ & $\begin{array}{l}46 \\
47 \\
65 \\
61 \\
57\end{array}$ & $\begin{array}{l}3 \\
3 \\
4 \\
8 \\
8\end{array}$ & $\begin{array}{r}9 \\
15 \\
20 \\
7 \\
7\end{array}$ & $\begin{array}{r}5 \\
14 \\
13 \\
7 \\
8\end{array}$ & $\begin{array}{l}1 \\
7 \\
8 \\
6 \\
4\end{array}$ \\
\hline & & Total & 276 & & 58 & 47 & 26 \\
\hline B & $\begin{array}{l}6 \\
7 \\
8\end{array}$ & $\begin{array}{c}16 \\
16 \\
\text { over } 20\end{array}$ & $\begin{array}{l}60 \\
58 \\
76\end{array}$ & $\begin{array}{l}8 \\
9 \\
3\end{array}$ & $\begin{array}{l}3 \\
3 \\
2\end{array}$ & $\begin{array}{l}6 \\
6 \\
4\end{array}$ & $\begin{array}{l}2 \\
0 \\
0\end{array}$ \\
\hline \multirow{3}{*}{$\mathbf{A}$} & & Total & 194 & & 8 & 16 & 2 \\
\hline & $\begin{array}{r}9 \\
10 \\
11 \\
12 \\
13\end{array}$ & $\begin{array}{l}16 \frac{1}{2} \\
17 \frac{1}{2} \\
17 \\
18 \frac{1}{2} \\
19\end{array}$ & $\begin{array}{l}73 \\
73 \\
46 \\
48 \\
55\end{array}$ & $\begin{array}{l}14 \\
26 \\
21 \\
33 \\
36\end{array}$ & $\begin{array}{r}4 \\
1 \\
0 \\
22 \\
2\end{array}$ & $\begin{array}{l}4 \\
5 \\
5 \\
0 \\
2\end{array}$ & $\begin{array}{l}0 \\
0 \\
0 \\
1 \\
0\end{array}$ \\
\hline & & Total & 295 & & 9 & 16 & 1 \\
\hline
\end{tabular}

* Time since members first joined training establishment.

\section{Experimental Method}

Each of the experiments carried out under normal living conditions may be roughly divided into three parts: (1) the period before occupation, when the air-infection was minimal; (2) the period of occupation, during which there were varying degrees of activity and varying degrees of air-infection; and (3) the period after occupation, during which air infection began to diminish. In each of these periods air samples were taken at intervals. For the majority of the observations the medium used was blood agar, incorporating crystal violet in a concentration of 1 in $1,000,000$. Some observations were made using ordinary blood-agar plates in order to ascertain the numbers in the air of all the bacteria (i.e. "all organisms") which could be cultivated on this more generally favourable medium. The plates were incubated aerobically at $37^{\circ} \mathrm{C}$. for about twenty-four hours and the colonies were then counted with the aid of a plate microscope. On the plates relating to each air sample counts were made of: (1) all colonies present (2) the $\beta$-haemolytic colonies resembling streptococci, and (3) the $\alpha$-haemolytic colonies resembling streptococci. The results were expressed as the number of bacteriacarrying particles per cubic foot of air-this corresponds to the number which would be inhaled during three to six minutes.

A proportion of the $\beta$-haemolytic bacteria was filmed, tested for soluble haemolysin production, grouped by Lancefield's method, and typed by slide agglutination. Almost all the organisms examined in this way were found to be $\beta$-haemolytic streptococci of Group A and are referred to as Streptococcus pyogenes. Typing by slide agglutination suggested that the majority of the $\beta$-haemolytic 


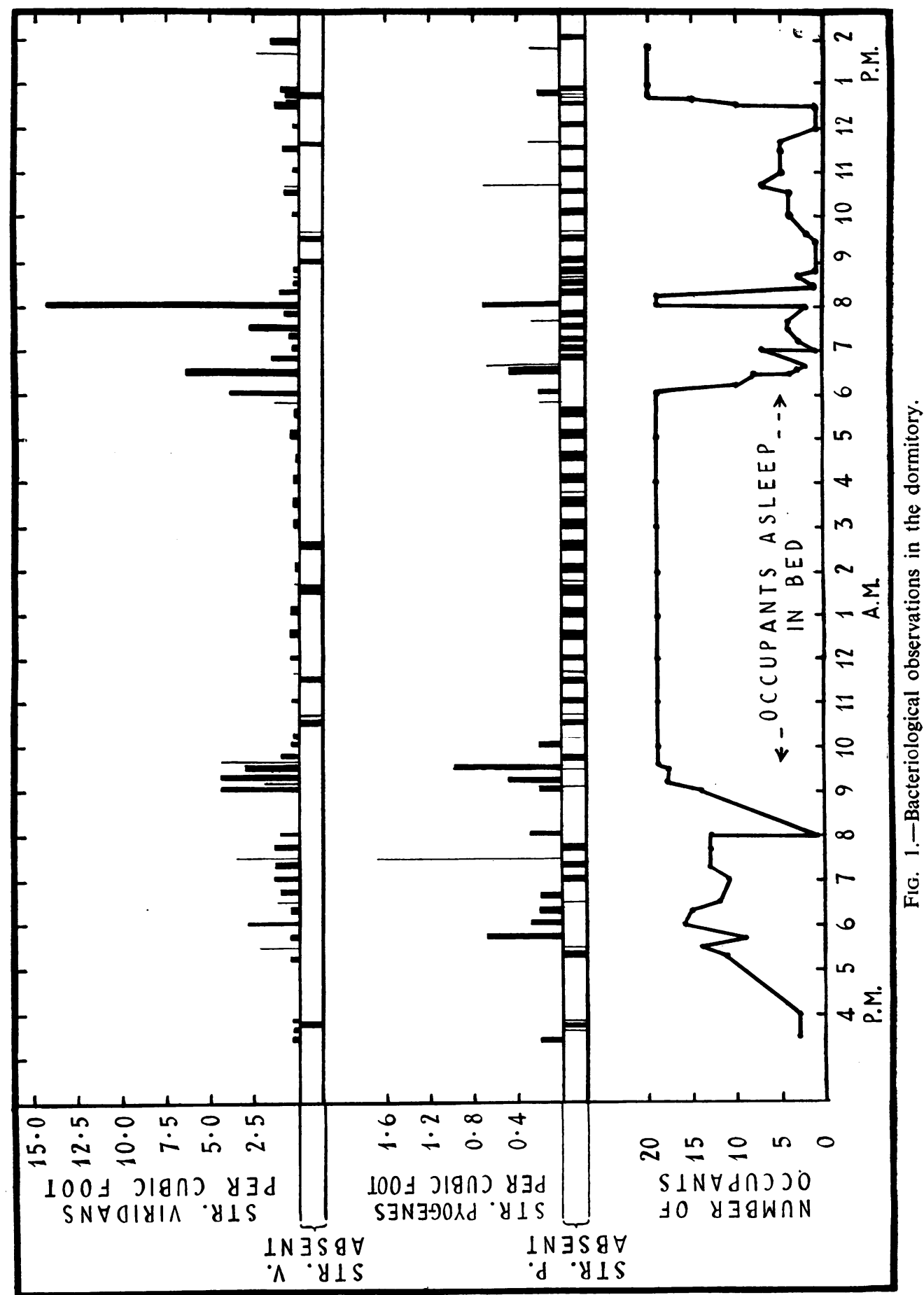

streptococci were Type 1 , but the results were not entirely satisfactory and this aspect of the investigation is being continued. All strains recovered from various clinical manifestations, such as simple tonsillitis, scarlet fever, and otitis media, were of low mouse virulence, the average lethal dose being 900,000 organisms.

A proportion of the $\alpha$-haemolytic colonies resembling streptococci were examined for production of green pigment on heated blood agar, morphology (chain formation) in broth culture, and for bile solubility and inulin fermentation; practically all appeared to be Streptococcus viridans (on the basis of these differential tests) and all were counted as such. On ordinary blood agar there were a relatively large number of staphylococcal colonies, which produced zones of haemolysis of varying types; these were distinguished from the streptococci by their larger size and opacity. Very few staphylococci grew on the crystal-violet blood-agar plates. 
Bacteriological Observations in a Dormitory

The dormitory chosen was one of the two used by group 2 (Table 2 ) in the section which suffered most heavily during the epidemic. Of the 24 persons using the dormitory 6 were in hospital; of the remaining 18 , one-third were carriers of $\beta$-haemolytic streptococci. The room was fairly large and appeared to be well ventilated. During darkness (5.15 p.m. to 7.45 a.m.) some of the windows were open behind the black-out curtains and, in fact, the presence of a small draught was noticeable in parts of the room near the windows.

The slit sampler was placed in the centre of the dormitory and was about $8 \mathrm{ft}$. $(2 \cdot 4 \mathrm{~m}$.) from the foot of the nearest beds. Bacteriological observations of the air (75 in all) were made at intervals during 24 hours of normal occupation and the results are given in Table 3, and Fig. 1.

TABLE 3

\section{OBSERVATIONS IN THE DORMITORY}

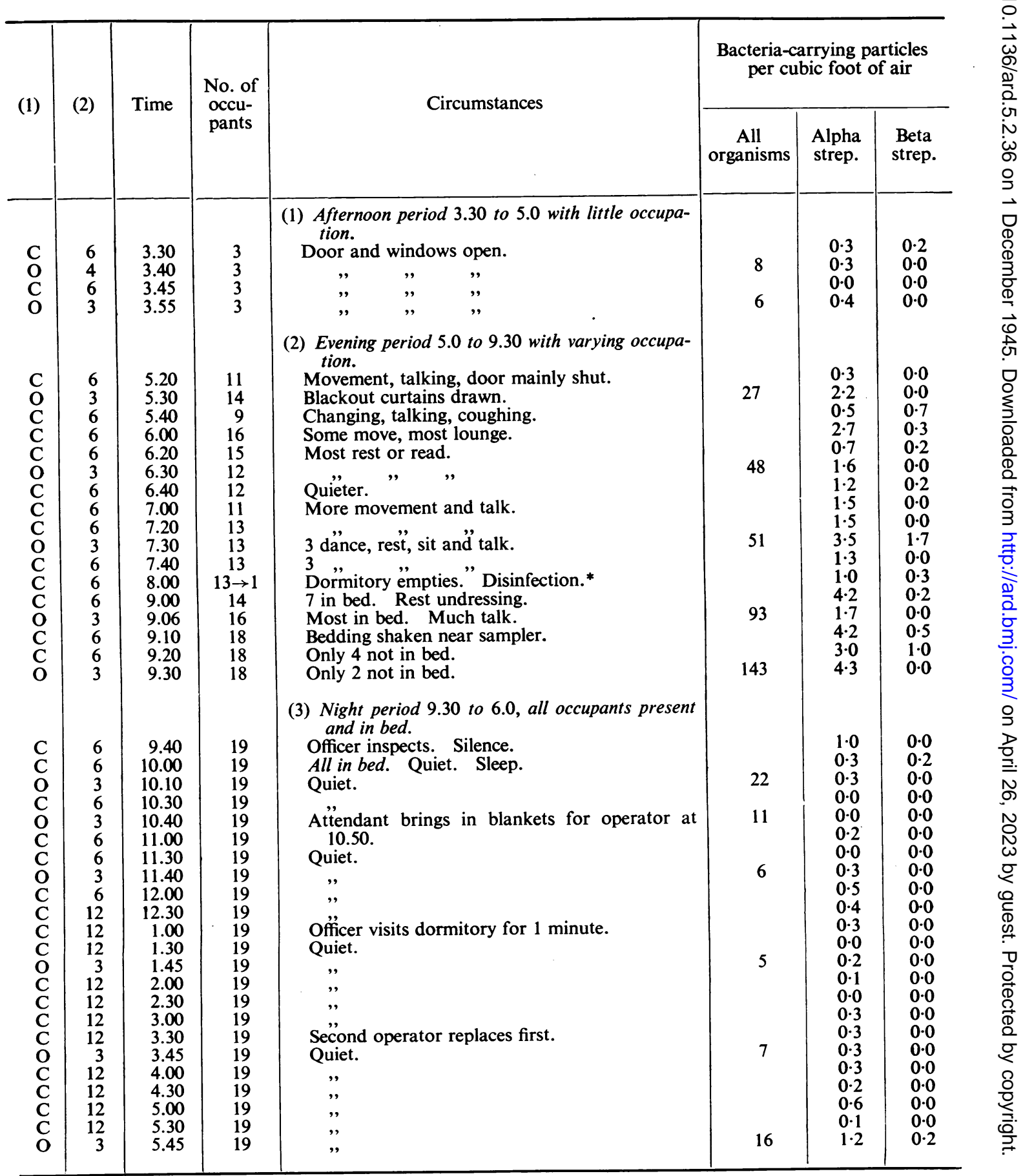


TABLE 3-continued

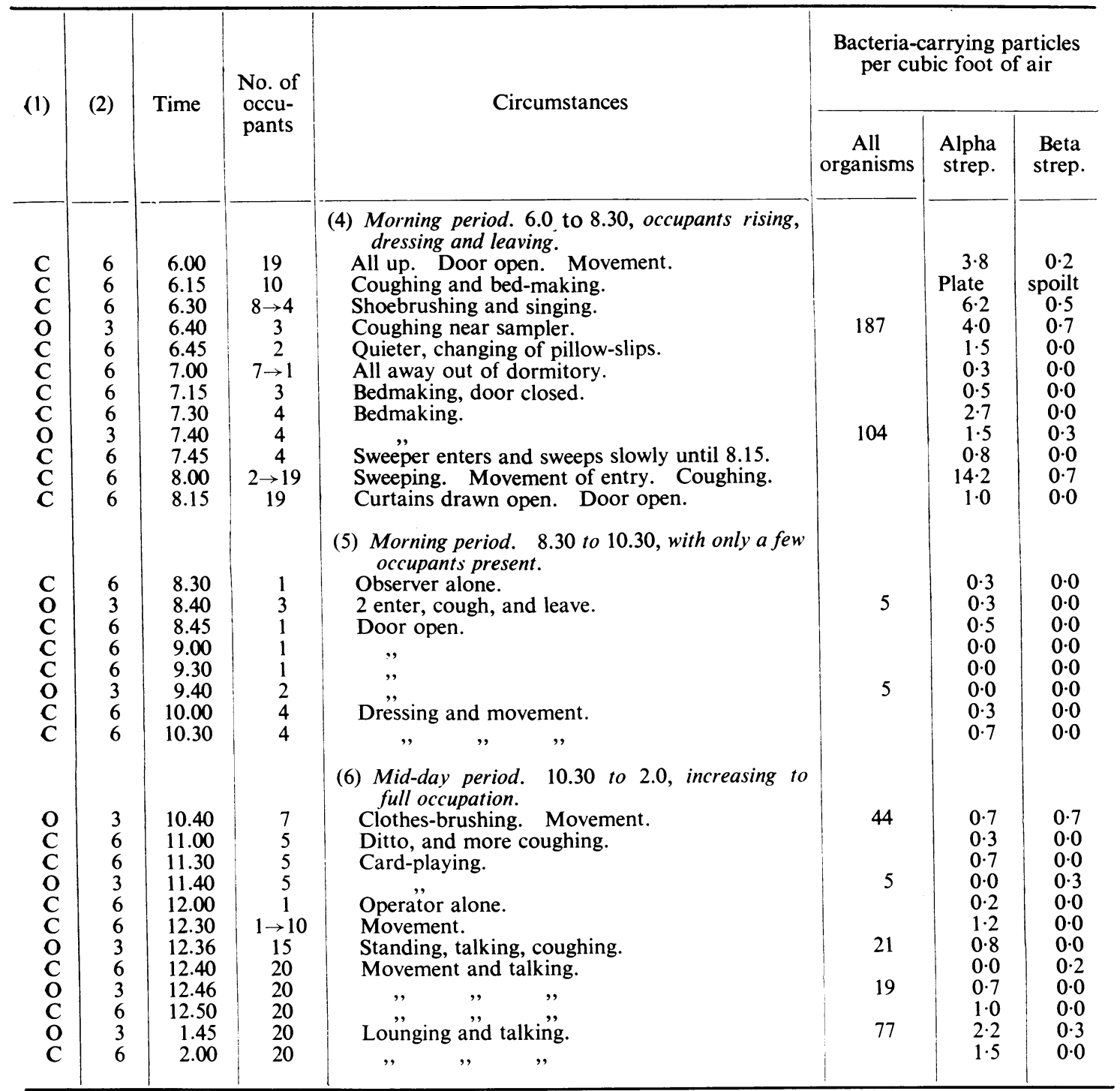

* Disinfection $=$ orderly gave about 30 puffs of Dettol into the air from a "flit" gun.

(1) $\mathrm{C}=$ crystal-violet blood-agar plate. $\mathrm{O}=$ ordinary blood-agar plate.

(2) = Number of cubic feet of air sampled.

It will be seen that this experiment was divided into six periods:

(1) From 3.30 to 5.0 p.m., the dormitory was unoccupied except for the operators. The amount of airinfection was small; the average numbers of bacteriacarrying particles per cubic foot of air being: Str. pyogenes $0 \cdot 05$, Str. viridans $0 \cdot 25$, and “ all organisms " 7 .

(2) From 5.0 to 9.30 p.m. there was irregular occupation with variable activity, the youths coming in, going out, walking about, lounging, chatting, reading, etc. There were about twelve youths present at any one time. The amount of air-infection was considerably greater, on an average per cubic foot of air: Str. pyogenes $0 \cdot 3$, Str. viridans $2 \cdot 1$, and " all organisms" 72 .

(3) From 9.30 p.m. to 6.0 a.m. the 18 occupants were asleep in bed; the operator was seated quietly at about 6 feet $(1.8 \mathrm{~m}$.) from the sampler. The amount of airinfection was again small being on an average per cubic foot of air: Str. pyogenes 0.02 , Str. viridans 0.30 , and $\stackrel{\sim}{\sigma}$ "all organisms" 11 .

(4) From 6.0 to 8.30 a.m. there was considerable activity, the youths leaving their beds, dressing, leaving $\omega$ and re-entering the dormitory, bedmaking and brushing their clothes; the floor was gently swept during this period. The amount of air-infection was again con- $\bar{\Phi}$ siderably increased, being on an average per cubic foot $\stackrel{\oplus}{+}$ of air: Str. pyogenes $0 \cdot 22$, Str. viridans $3 \cdot 3$, and " all organisms" 145.

(5) From 8.30 to 10.0 a.m. the dormitory was un- $\overrightarrow{\mathbb{D}}$ occupied. The amount of air-infection was small, being $\overrightarrow{\mathbb{D}}$ on an average per cubic foot of air: Str. pyogenes 0.00 , 응 Str. viridans $0 \cdot 25$, and " all organisms" 5 .

(6) From 10.0 a.m. to 2.0 p.m. the dormitory was occupied irregularly with variable activity. The amount of air-infection was again increased, being on an average per cubic foot of air: Str. pyogenes $0 \cdot 15$, Str. viridans $0 \cdot 78$, and " all organisms" 33. 
The following points are of major interest. (1) The amount of air-infection was very small, indeed Str. pyogenes was almost absent, not only when the dormitory was unoccupied but also when all the occupants were present but asleep. (2) The bacterial content of the air diminished rapidly after the cessation of occupation or activity, for example, Str. viridans was present in relatively large numbers immediately before retirement $(9.30$ p.m. $)$, but within twenty minutes after retirement most had disappeared. A similar rapid clearance of the considerable air-infection at 6.40 and 8.0 a.m. in the morning, was also observed. (3) The actual numbers of organisms found in the air at different times is of interest, especially the numbers of Str. pyogenes, which formed only a small proportion, less than $0.5 \%$, of all the organisms which could be cultivated on ordinary blood agar. (4) The number of bacteria-carrying particles present in the air appeared to vary directly with the number of occupants and the amount of their activity. This correlation was most complete in the case of Str. viridans, but it appeared that the total number of airborne bacteria and the number of Str. pyogenes varied in the same way.

\section{Bacteriological Observations in the Cinema}

The entertainment hall, in which the cinema performances were given, was a large lofty room $90 \mathrm{ft}$. $\times 50 \mathrm{ft} . \times 15 \mathrm{ft} .(27 \mathrm{~m} . \times 15 \mathrm{~m} . \times 4.5 \mathrm{~m}$.$) . All$ the windows were shut and draped with black-out curtains, and, although the two doors were opened intermittently, the air became somewhat oppressive with the temperature rising $6^{\circ} \mathrm{F}$. in about an hour. About 300 youths were present. They sat on benches arranged on either side of a central passage about $12 \mathrm{ft}$. (3.6 m.) wide, which was kept clear.

The air sampler was placed in the central passage, and was partially screened to prevent droplets from the nearest members of the audience falling directly into, or close to, the sampler. Observations (40 in number) were made and these are illustrated in Fig. 2; owing to the present restriction on paper, the tables showing detailed results are not included for this and subsequent experiments.

This experiment may conveniently be divided into three periods:

(1) From 6.30 to 8.0 p.m. the hall was unoccupied except for from two to six persons. The numbers of bacteria-carrying particles per cubic foot of air were small, averaging: Str. pyogenes 0.02 , Str. viridans $0 \cdot 27$, " all organisms" 10.

(2) From 8.0 to 11.0 p.m. the hall was occupied. Half an hour elapsed before all 300 occupants were present. During this time there was a progressive increase in the amount of air-infection, a peak value (Str. pyogenes $0 \cdot 7$, Str. viridans $5 \cdot 8$ per cubic foot) being reached by 8.30 p.m. During occupation the bacterial

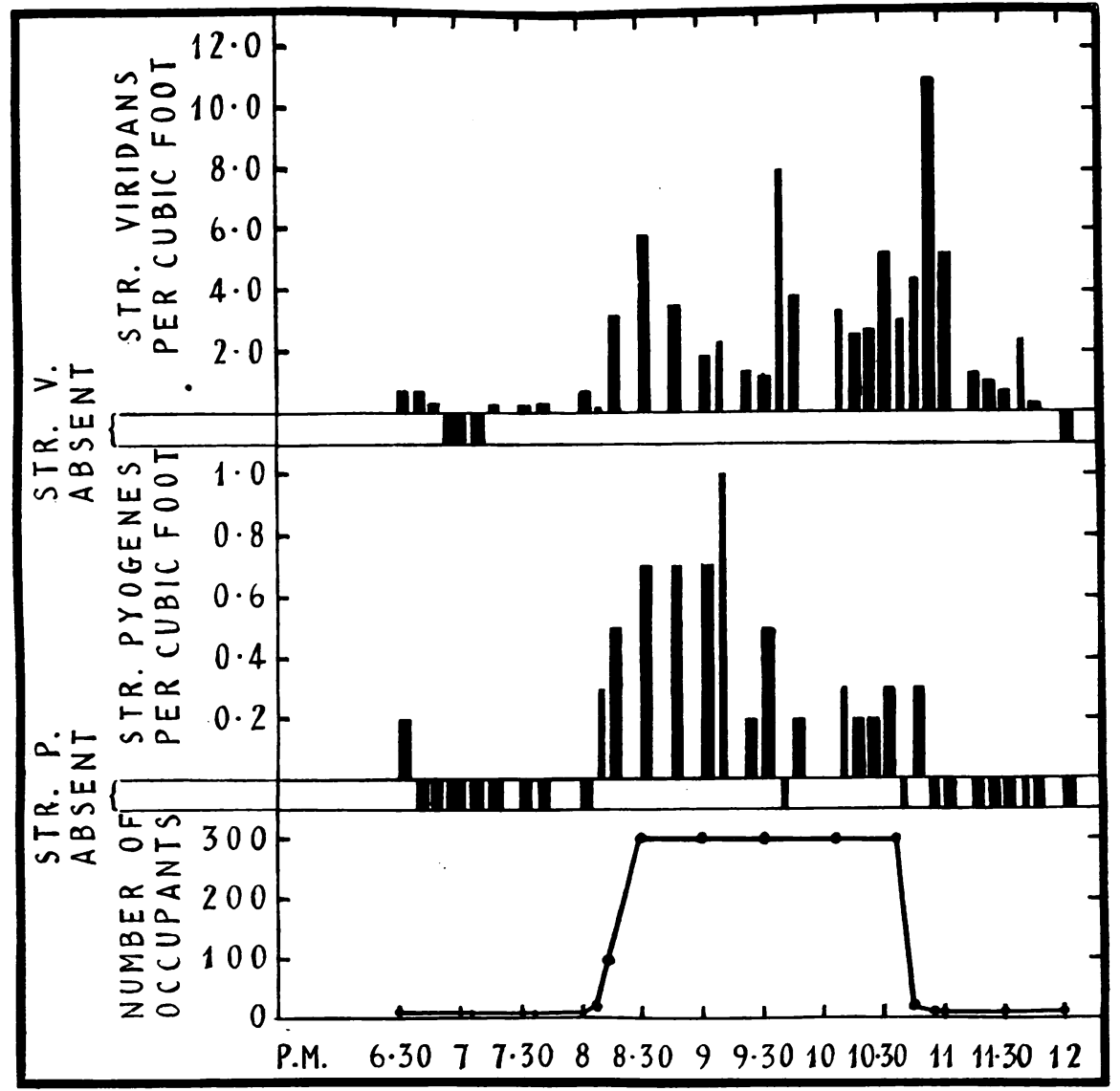

FIG. 2.-Bacteriological observations in the cinema. 
content of the air varied irregularly; for the period the average numbers of bacteria-carrying particles per cubic foot of air were: Str. pyogenes 0.33, Str. viridans 3.5, "all organisms" 62. At 10.45 p.m. the occupants started to leave the hall, benches were moved, and the floor was swept; this disturbance presumably caused the high peak value recorded for Str. viridans at 10.53 p.m. This large amount of air-infection was rapidly cleared, there being a $90 \%$ reduction within the following twenty minutes.

(3) From 11.0 to 12.0 p.m. the hall was unoccupied except for the operator; the numbers of bacteria-carrying particles per cubic foot of air were small: Str. pyogenes $0 \cdot 0$, Str. viridans $1 \cdot 5$, “ all organisms " 26.

The viridans content of the air varied irregularly during occupation of the hall and no appreciable progressive increase during continued occupation was observed. The particularly high viridans counts recorded at the beginning and end of the experiment, and at one interval during the performance, corresponded with the increased activity which prevailed at these times. It appeared, therefore, that the amount of air-infection was deter- mined by the degree of activity of the occupants rather than by the number of occupants.

Small and irregular numbers of Str. pyogenes were found, the counts being comparable with those क recorded for the experiment in the dormitory. This is of interest in view of the fact that the cinema hall $\stackrel{\vec{S}}{\overrightarrow{9}}$ was relatively (5 times) more crowded than the dormitory.

\section{Bacteriological Observations in the Schoolroom}

The schoolroom was spacious, being $100 \mathrm{ft}$. $25 \mathrm{ft}$. $12 \mathrm{ft}$. $(30 \mathrm{~m}$. $7.5 \mathrm{~m} . \quad 3.6 \mathrm{~m}$.). There were nine windows, all of which were closed and draped, and three doors, only two of which were used. The floor was made of dull polished wood and had been mopped three hours previous to the start of the experiment. The pupils (52 in number) or were seated on benches distributed throughout the iv room; they made up three classes, each of which of was in charge of a master who walked about and 음 talked freely. There was little talking by the pupils; coughing was negligible and only one or

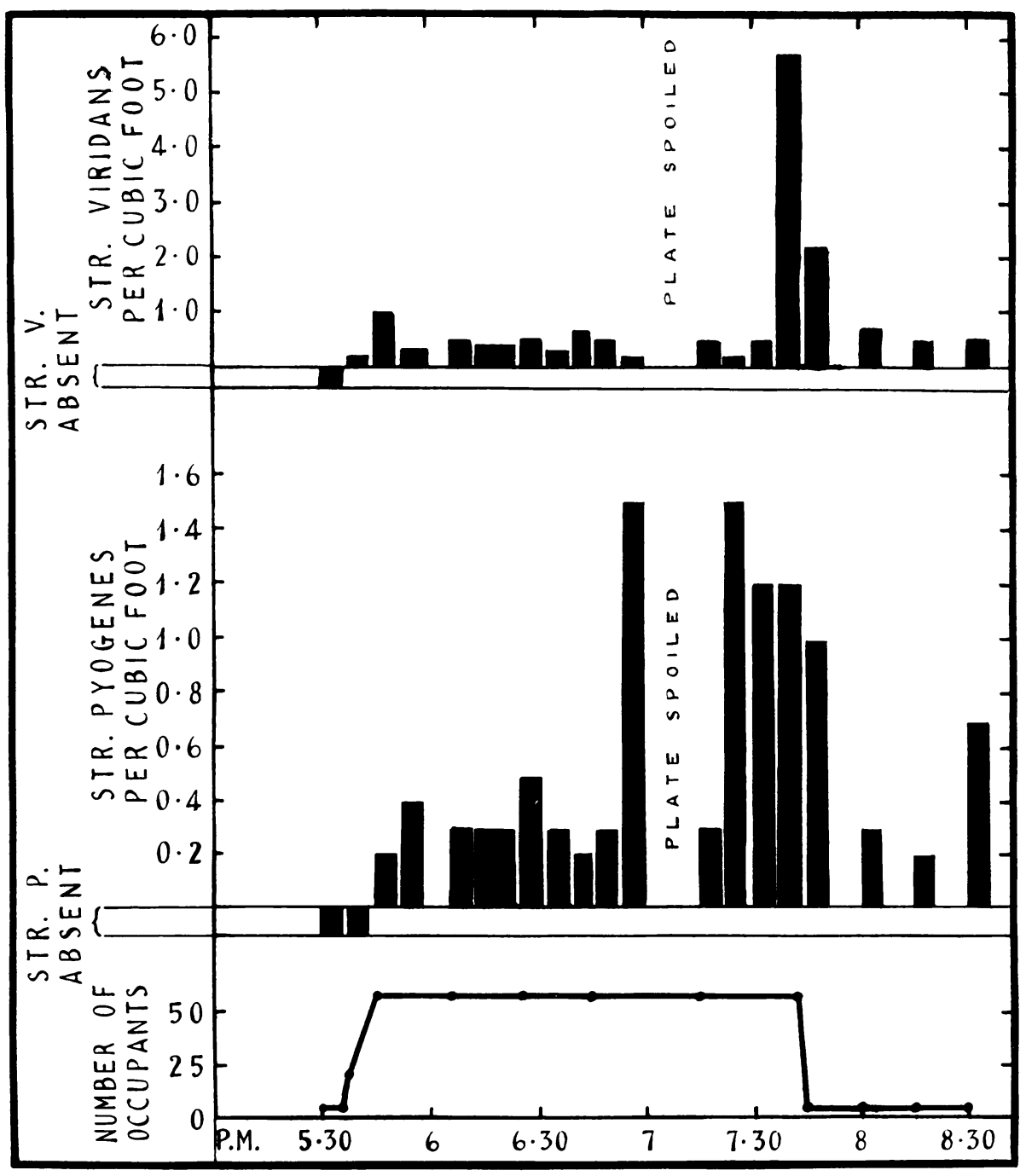

FIG. 3.-Bacteriological observations in the schoolroom. 


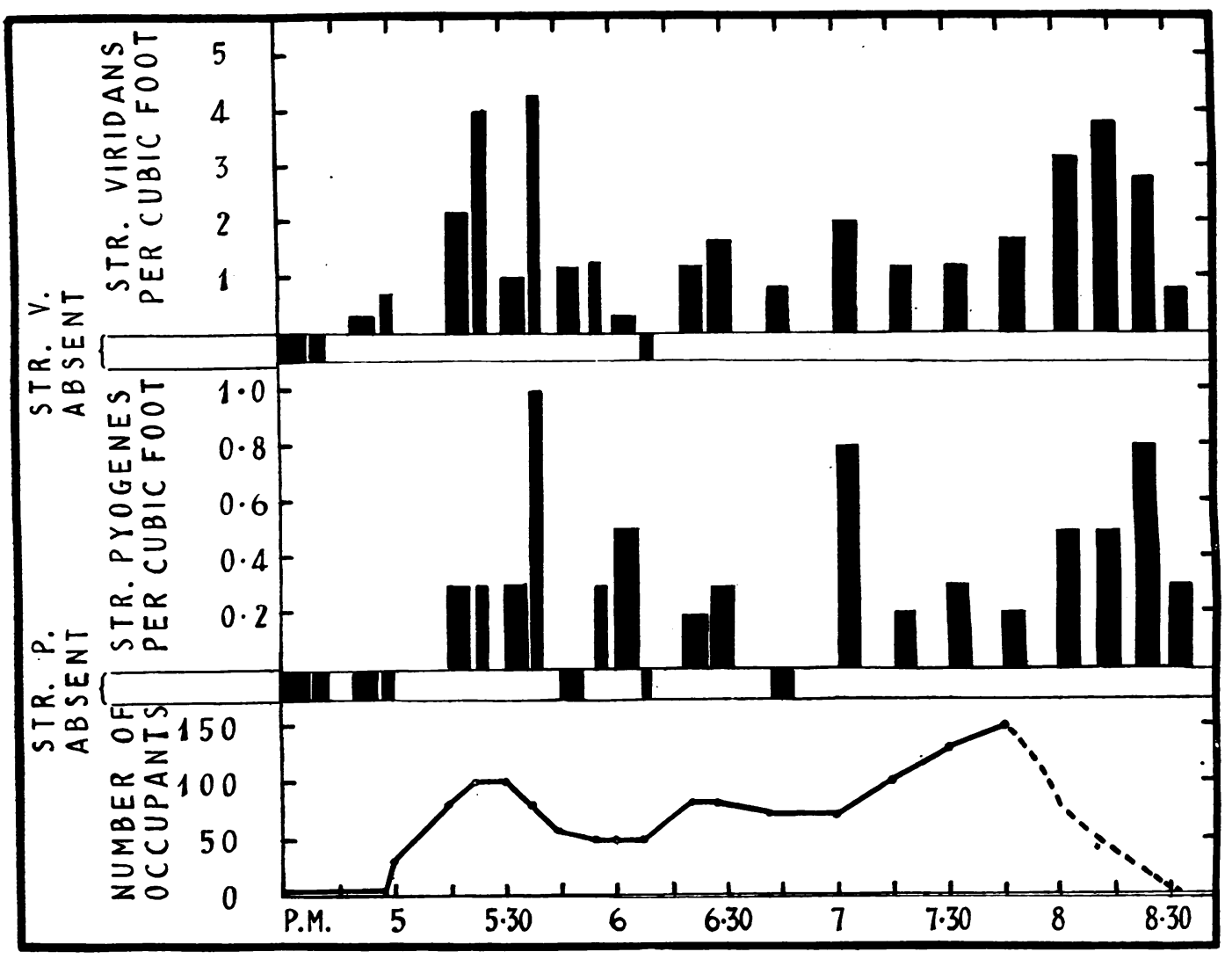

Fig. 4.-Bacteriological observations in the recreation room.

two sneezes occurred, these being far away from the slit sampler. A central position was chosen for the slit sampler, which was partially screened from the pupils in its immediate vicinity. Observations were made throughout the experiment and the results are shown in Fig. 3.

Before the room was occupied by the pupils ( 5.30 to 5.40 p.m.) the numbers of bacteria-carrying particles per cubic foot of air were small (Str. pyogenes 0.0 and Str. viridans 0.1 . Within a few minutes of the pupils entering, the air-infection became greatly increased in amount. During occupation (5.40 to 7.40 p.m.) the average numbers of bacteria-carrying particles per cubic foot of air were: Str. pyogenes 0.63 , Str. viridans 0.87 , and " all organisms" 26. The large numbers of Str. viridans (5.7 particles per cubic foot) present in the air at the end of occupation might have been due to: (1) the increased restlessness and talking of the pupils; (2) the talking near the sampler by the master; or (3) the disturbance due to the pupils starting to leave the classroom (this occurred only during the last six minutes of occupation).

The relatively large numbers of Str. pyogenes also found towards the end of occupation may be similarly explained. After the end of occupation there was a rapid reduction (about $90 \%$ in twenty minutes) in the numbers of airborne Str. viridans. It should be noted, however, that the amount of air-infection after occupation remained for an appreciable time as great as the average amount of air-infection during occupation; during the first twenty-five minutes after occupation, the numbers of bacteria-carrying particles per cubic foot were Str. viridans 1.5 and Str. pyogenes 0.65 ; during the second twenty-five minutes after occupation, the numbers were Str. viridans 0.50 and Str. pyogenes 0.45 .

Relatively larger numbers of particles carrying Str. pyogenes, and relatively smaller numbers of particles carrying Str. viridans, were present in the air of the schoolroom than in the air of the dormitory or cinema hall.

\section{Bacteriological Observations in the Recreation Room}

In size, the room was $90 \mathrm{ft} . \times 30 \mathrm{ft} . \times 12 \mathrm{ft}$. $(27 \mathrm{~m} . \times 9 \mathrm{~m} . \times 3.6 \mathrm{~m}$.). The floor was covered with linoleum, the windows were shut, and of the two doors one was opened intermittently. Four fan-ventilators set in the roof were moving slowly. During the two hours before the experiment the room was unoccupied. The air sampler was placed to one side of the room-about $8 \mathrm{ft}$. $(2 \cdot 4 \mathrm{~m}$.) from the wall-and not quite half-way down the room from the door of entry at one end. The sampler was partially screened as in previous experiments. The results of the observations are shown in Fig. 4.

Before the room was occupied, the numbers of bacteriacarrying particles per cubic foot of air were small: Str. pyogenes $0 \cdot 0$, Str. viridans $0 \cdot 25$, and "all organisms" 7 . During three and a half hours of occupation the number of occupants present varied between 40 and 150. They spent the time in playing cards, reading, talking, and lounging; a few of the more active occupants danced 
and played games such as table tennis, etc. The atmosphere quickly became oppressive. The average numbers of bacteria-carrying particles per cubic foot of air were: Str. pyogenes $0 \cdot 38$, Str. viridans $1 \cdot 80$, and " all organisms" 65.

The bacterial content of the air was then not significantly greater than that of the air of the premises previously investigated, in which the air had seemed to be relatively fresh. The streptococcal $(\alpha$ and $\beta$ ) content of the air during the period of observation ( $3 \frac{1}{2}$ hours), varied within rather narrow limits, except for the higher counts recorded at times when there was much entering or leaving.

\section{Discussion}

In order to facilitate discussion of the observations made in the dormitory, cinema hall, school and recreation rooms, some of the more important results are summarized below, where the average numbers of bacteria-carrying particles per cubic foot of air, for the periods before and during occupation, are shown.*

\begin{tabular}{|c|c|c|c|c|}
\hline & $\underset{\text { tory }}{\text { Dormi- }}$ & $\begin{array}{c}\text { Cinema } \\
\text { Hall }\end{array}$ & $\begin{array}{l}\text { School } \\
\text { Room }\end{array}$ & $\begin{array}{l}\text { Recrea- } \\
\text { Room }\end{array}$ \\
\hline $\begin{array}{ll}\text { Str. pyogenes (per cu. ft.) } \\
\text { Before occupation }\end{array}$ & $\begin{array}{l}0.05 \\
0.22\end{array}$ & $\begin{array}{l}0.02 \\
0.33\end{array}$ & $\begin{array}{l}0.00 \\
0.63\end{array}$ & $\begin{array}{l}0.00 \\
0.38\end{array}$ \\
\hline $\begin{array}{ll}\text { Str. viridans (per cu. ft.) } & \\
\text { Before occupation } & \ldots \\
\text { During occupation } & \ldots\end{array}$ & $\begin{array}{l}0.25 \\
1.91\end{array}$ & $\begin{array}{l}0.27 \\
3 \cdot 50\end{array}$ & $\begin{array}{l}0 \cdot 10 \\
0 \cdot 87\end{array}$ & $\begin{array}{l}0.25 \\
1.80\end{array}$ \\
\hline $\begin{array}{ll}\text { All organisms (per cu. ft.) } \\
\text { Before occupation } \\
\text { During occupation }\end{array}$ & $\begin{array}{r}7 \\
74\end{array}$ & $\begin{array}{l}10 \\
62\end{array}$ & $2 \overline{6}$ & $\begin{array}{r}7 \\
65\end{array}$ \\
\hline 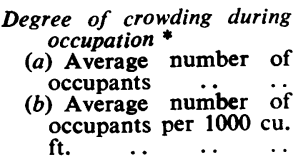 & 0.8 & 300 & 1.9 & $\begin{array}{l}75 \\
2 \cdot 3\end{array}$ \\
\hline Degree of activity .. & Great & Moderate & Little & Moderate \\
\hline Predominant type of activity & $\begin{array}{l}\text { Ambu- } \\
\text { latory }\end{array}$ & $\begin{array}{l}\text { Seden- } \\
\text { tary }\end{array}$ & $\begin{array}{l}\text { Seden- } \\
\text { tary }\end{array}$ & $\begin{array}{l}\text { Ambu- } \\
\text { latory }\end{array}$ \\
\hline
\end{tabular}

* Data for " occupation" relate only to wakeful occupation.

The magnitudes of the bacterial content of the air in the various premises, under very different conditions of occupation are of considerable interest, especially in the case of Str. pyogenes. Particles carrying Str. pyogenes were found in the air of each of the four rooms examined during the period of their occupation by the members of the establishment; the number of these infected particles per cubic foot of air varied, in different air-samples, from 0 to an upper limit of $1 \cdot 7,1.0,1 \cdot 5$, and 1.0 , respectively, in the four rooms; the average numbers per cubic foot of air were $0.22,0.33,0.63$, and 0.38 . From these figures, it will be seen that during occupation of such premises, a member of the establishment would be exposed, on an average, to a degree of air-infection of the order of $0.4 \mathrm{Str}$. pyogenes-carrying particles per cubic foot of air; this would mean that about six infected particles would be inhaled every hour. The amount of airinfection was much smaller when the rooms were unoccupied (except for the operators) and, in the case of the dormitory, when the occupants were asleep. Of all the bacteria-carrying particles recovered from the air, those carrying Str. pyogenes formed only a small proportion (usually less than $0.5 \%)$.

From the average findings tabulated above for Str. pyogenes, for Str. viridans, and for "all organisms," it will be seen that the amount of airinfection was much greater during occupation than before occupation. Further evidence of the dependence of air-infection upon the extent of occupation is seen in the case of the cinema hall, where the degree of crowding was greater than in any of the other rooms and the numbers of Str. viridans present in the air were larger. However, the degree of air-infection could not be correlated directly with the degree of crowding. For instance, the greatest air-infection with Str. pyogenes occurred in the school, the second least crowded of the four rooms; the greatest air-infection by " all organisms " was found in the dormitory, which was the least crowded; the Str. viridans concentration in the air of the dormitory was more than twice that of the air of the schoolroom, although the dormitory was only half as crowded. Furthermore, at night, when the dormitory was fully occupied, but when the occupants were in bed and asleep, the air-infection was minimal.

There appeared, on the other hand, to be a fairly close correlation between the amount of air-infection and the total amount of activity, such as walking, dressing, and other body movements. This correlation was most complete in the case of Str. viridans and of "all organisms"; the number of airborne particles carrying Str. pyogenes varied irregularly, but, as the numbers of these particles were very small, close correlation could not be expected. The amount of activity could not, of course, be measured and was assessed as far as possible by visual impression. The amount of activity which was maintained on an average over the periods of occupation was greatest in the dormitory (wakeful occupation only) and least in the schoolroom; correspondingly, the degree of airinfection with Str. viridans and "all organisms" was highest in the dormitory and lowest in the schoolroom. Maximal activity occurred at the beginning and at the end of the periods of occupation, when many persons were moving about (entering or leaving the room) and when there was often movement of benches and sweeping of the floor; at these times, maximum amounts of airinfection were usually recorded. Mention has already been made of the very low degree of airinfection found in the dormitory at night, when, although all occupants were present, there was practically no activity or movement.

It appears then that while the magnitude of airinfection in occupied premises depended to some extent upon the degree of crowding, it depended to a greater extent upon the amount of activity of the occupants. This suggests that a greater part of the air-infection was produced by liberation into the 
air, by the activities of the occupants, of infected dust particles from clothing, floors, and furnishings, than by direct introduction of respiratory dropletnuclei into the air. This conclusion is in accordance with the results obtained in a number of studies published in recent years. Several investigators have reported that Str. pyogenes are often present in large numbers on the clothing and bedclothes of infected persons, and in the dust of the floor and furnishings of the rooms occupied by these persons; moreover, some investigators have found that, in infected hospital wards, such activities as bedmaking, sweeping, the toilet of the patients, and the serving of meals, regularly brought about a very great increase in the number of airborne Str. pyogenes (White, 1936; Brown and Allison, 1937; van den Ende, Lush and Edward, 1940; Cruickshank, 1941; Hare, 1941; Thomas and van den Ende, 1941; Wright, Cruickshank and Gunn, 1944; Hamburger, Puck, Hamburger, and Johnson, 1944; and Hamburger, Green, and Hamburger, 1945). Similar dependence of the magnitude of aerial infection upon the amount of activity likely to stir up dust has also been found in the case of counts of the total serial flora of occupied premises (Torrey and Lake, 1941; Challinor, 1943; Challinor and Duguid, 1944). Owing to the relationship between acute rheumatism and haemolytic streptococcal infection, control of the spread of the latter disease may well be expected to reduce the relapse rate in hospitals used for acute rheumatism. Coburn (1939) has utilized this procedure successfully. On the other hand, Wheeler and Jones (1942) while effecting a reduction in bacteria content of the air of one ward were not rewarded with any lowering in the incidence of throat carriers or in relapse rate. The evidence on this point is equivocal. In the present instance it must be stressed that the population at risk were normal youths, and the outbreak was not followed by a wave of acute rheumatism.

\section{Summary}

1. Observations were carried out with a slit sampler on the bacterial content of the air in various occupied premises of a residential training establishment during an epidemic of haemolytic streptococcal throat infections.

2. The average amounts of air-infection with Str. pyogenes in a dormitory, in a cinema hall, in a schoolroom, and in a recreation room were, respec- tively, $0.22,0.33,0.63$, and 0.38 infected particles per cubic foot of air, when these premises were occupied to the extent of $0.8,3 \cdot 8,1 \cdot 9$, and 2.3 occupants per $1,000 \mathrm{cu}$. ft. of room space. Str. pyogenes formed only a small proportion, usually less than $0.5 \%$, of the airborne bacteria.

3. The amount of air-infection with Str. pyogenes, with Str. viridans, and with " all organisms," was appreciable only during periods when the premises were occupied; after vacation of the premises this air-infection diminished within a short time (a quarter to half an hour) to a very low level; such a low level was also found in the periods prior to occupation and, in the case of the dormitory, at night when the occupants were asleep.

(4) Air-infection depended largely upon occupation, but the amount of air-infection could not be correlated directly with the degree of crowding; closer correlation was found between the amount of air-infection and the amount of activity of the occupants. Presumably the air-infection was produced by liberation into the air of infected dust particles, this being brought about by the activity of the occupants.

We wish to acknowledge our indebtedness to ViceAdmiral Sir Sheldon F. Dudley, Medical Director General, for permission to publish this report, and to Professor T. J. Mackie for his advice and provision of laboratory facilities.

\section{REFERENCES}

Bourdillon, R. B., Lidwell, O. M., and Thomas, J. C. (1941). J. Hyg.

41, 197. and Lovelock, J. E. (1942). Brit. med. J. 1, 42.

Bradley, W. H. (1932). Quart. J. Med., 25, 79 .

Bradley, W. H. (1932). Quart. J. Med, 25, 79. Hyg., 37, 1.

Brown, W. A., and Allison, V. D. (1937). J. Hyg., 37,

Buchbinder, L. (1942). J. Amer. med. Ass.,

Challinor, S. W. (1943). J. Hyg., 43, 16.

Coburn, A. F. (1931). The factor of infection in the rheumatic state. Williams and Wilkins, Baltimore.

Collis, W. R. F. (1931). Lancet, 1, 1341

Cruickshank, R. (1941). Ibid., 1, 493.

Glover, J. A. (1930). Ibid., 1, 499.

Green, C. A. (1942). Ann. Rheum. Dis., 3, 4.

Hamburger, M., Puck, T. T., Hamburger, V. G., and Johnson, M. A. (1944). J. infect. Dis., 75, 79.
Green, M. J., and Hamburger, V. G. (1945). Ibid., 77, 68.

Hare, R. (1941). Lancet, 1, 85.

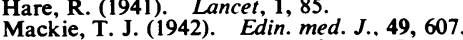

Mackie, T. J. (1942). Edin. med. J., 49,

Mudd, S. (1944). Ibid., 11, 67.

Thomas, J. C., and van den Ende, M. (1941). Ibid., 1, 953.

Torrey, J. C., and Lake, M. (1941). J. Amer. med. Ass., 117, 1425. Wheeler, D. S. M., and Jones, T. D. (1942). Aerobiology, Amer. Assoc. Adv. Sci. pub. No. 17, Washington, D.C., p. 237.

White, E. (1936). Lancet, 1, 941 .

Wright, J., Cruickshank, R., and Gunn, W. (1944). Brit. med. J., 1, 611 .

Van den Ende, M., Lush, D., and Edward D. G. ff. (1940). Lancet, 11,133 .

\section{PART II}

Observations recorded here were made in order to investigate more fully the mechanisms whereby infection is introduced into the air from the noses and throats of infected persons. The mechanisms considered were: (1) Direct introduction into the air of infected droplet-nuclei, during sneezing, coughing, and speaking; and (2) liberation into the air of infected dust-particles, either from the floors and furnishings of rooms, or from bedding, towels, handkerchiefs, and clothes, after these articles have been soiled by nasai secretion, sputum, or droplet-spray. Separate experiments were carried out, in each of which one of these modes of airinfection was artificially exaggerated, while the others were minimized as much as possible. Observations of the air-infection were made with the slit sampler (Bourdillon, Lidwell, and Thomas, 1941) as previously described. 
Air-Infection with Respiratory Droplet-nuclei

Observations were made of the bacterial content of the air in the immediate vicinity of four " throat carriers" of $\beta$-haemolytic streptococci, who, while playing a game of cards, talked, laughed, and coughed frequently and vigorously. The game was played in the middle of the dormitory already described. This dormitory had been unoccupied for ninety minutes preceding the experiment. During the experiment, only the four "carriers" and the operator were present. The "carriers" were grouped about the air sampler, being respectively $1 \frac{1}{2}, 2,4$, and $4 \mathrm{ft}$. $(45,60,120$, and $120 \mathrm{~cm}$.) from it, and facing either half or fully towards it. To minimize "dust-raising" movement was restricted to the requirements of the game.

Air samples (each of $12 \mathrm{cu}$. ft.) were taken before the "carriers" entered, then at intervals throughout the game (which lasted 1 hour 40 minutes) and finally after the "carriers" had left. The findings are shown below.

Numbers of Bacteria-carrying Particles per Cubic Foot of Air

\begin{tabular}{|c|c|c|c|c|}
\hline \multicolumn{2}{|c|}{$\begin{array}{l}\text { Time of } \\
\text { Operation }\end{array}$} & Circumstances & $\begin{array}{c}\text { Beta } \\
\text { Strep. }\end{array}$ & $\begin{array}{l}\text { Alpha } \\
\text { Strep. }\end{array}$ \\
\hline \multirow{2}{*}{\multicolumn{2}{|c|}{$\begin{array}{l}1.50-56 \text { p.m. } \\
2.20-32 \quad, \\
2.35-47,\end{array}$}} & Operator alone in dormitory & 0.0 & $0 \cdot 2$ \\
\hline & & $\ddot{\prime \prime} \quad, "$, & $\begin{array}{l}0 \cdot 0 \\
0 \cdot 1\end{array}$ & $\begin{array}{l}0 \cdot 0 \\
0 \cdot 0\end{array}$ \\
\hline $\begin{array}{l}2.53-05 \\
3.07-19 \\
3.21-33,\end{array}$ & , , & $\begin{array}{l}\text { Four " carriers" now present, } \\
\text { playing cards quietly with an } \\
\text { occasional cough. }\end{array}$ & $\begin{array}{l}0.0 \\
0.0 \\
0 \cdot 8\end{array}$ & $\begin{array}{l}0 \cdot 6 \\
0 \cdot 0 \\
0 \cdot 3\end{array}$ \\
\hline $\begin{array}{l}3.36-48, \\
3.50-02\end{array}$, & ", & $\begin{array}{l}\text { Playing noisily, with much loud } \\
\text { talking, laughter, singing and } \\
\text { coughing. }\end{array}$ & $\begin{array}{l}0.0 \\
0.1\end{array}$ & $\begin{array}{l}0.2 \\
0.3\end{array}$ \\
\hline $\begin{array}{l}4 \cdot 04-16 \\
4.18-30\end{array}$ & ,", & $\begin{array}{l}\text { Playing quietly with little talking } \\
\text { and infrequent coughing. }\end{array}$ & $\begin{array}{l}0 \cdot 0 \\
4 \cdot 7\end{array}$ & $\begin{array}{l}0.2 \\
0.0\end{array}$ \\
\hline $\begin{array}{r}4.32-44 \\
4.45-57 \\
5.00-12\end{array}$ & ,", & $\begin{array}{l}\text { Only the operator now present in } \\
\text { dormitory. }\end{array}$ & $\begin{array}{l}0 \cdot 1 \\
0 \cdot 3 \\
0 \cdot 0\end{array}$ & $\begin{array}{l}0.4 \\
0 \cdot 0 \\
0 \cdot 0\end{array}$ \\
\hline
\end{tabular}

During the control periods before and after the game few $\beta$ streptococci were present in the air. During the game greater numbers of $\beta$ streptococci were found in only 2 out of the 7 air samples taken. As both these samples were taken at times not corresponding to the period of the maximum talking and coughing, some mechanism other than the expulsion of droplet-spray may well have been responsible for this increase in the air-infection. In any case, the amount of air-infection found in the immediate vicinity of much vigorous talking, laughing, and coughing by four infected persons was very small; in fact, little greater than that found in the air at large of the institution buildings during their occupation $(0.2$ to 0.6 infected particles per cubic foot of air).

\section{Air-Infection with Dust from the Floor and Bedding}

Observations of the bacterial content of the air were made during sweeping and the shaking of bedclothes, in a dormitory usually occupied by 18 persons, 6 of whom were "throat carriers" of $\beta$ streptococci. The dormitory had not been swept for thirty hours before the experiment.

Six youths (not carriers of $\beta$-haemolytic streptococci) were employed to raise the dust. These, as also the two operators, were masked to prevent the expulsion of droplet-spray. Dust was raised in three different ways: (1) the youths marched repeatedly up and down the dormitory; (2) they swept the floor very vigorously, especially near the sampler; and (3) they shook, close to the sampler, various blankets, towels, and pillows belonging to the usual occupants of the dormitory. Observations were made during the period of each dust raising, and also during the periods before and after. The findings are shown below as numbers of

\begin{tabular}{|c|c|c|c|c|c|c|}
\hline \multicolumn{2}{|c|}{$\begin{array}{c}\text { Time of } \\
\text { observation }\end{array}$} & Circumstances & $\begin{array}{l}\text { Beta } \\
\text { strep. }\end{array}$ & $\begin{array}{l}\text { Alpha } \\
\text { strep. }\end{array}$ & $\begin{array}{c}\text { "All } \\
\text { organisms" }\end{array}$ & $\begin{array}{l}\text { Air } \\
\text { dust }\end{array}$ \\
\hline $\begin{array}{l}1.55-01 \\
2.04-10 \\
2.17-23\end{array}$ & $\begin{array}{l}\text { p.m. } \\
\text {," }\end{array}$ & Only the 2 operators present in the dormitory. & $\begin{array}{l}0.0 \\
0.0 \\
0.0\end{array}$ & $\begin{array}{l}0.0 \\
0.2 \\
0.0\end{array}$ & & $\begin{array}{l}1 \\
1 \\
1\end{array}$ \\
\hline $\begin{array}{l}2.29-35 \\
2.36-42\end{array}$ & ", & $\begin{array}{l}6 \text { youths marching continually up and down the dormi- } \\
\text { tory. }\end{array}$ & $\begin{array}{l}0 \cdot 2 \\
0 \cdot 0\end{array}$ & $\begin{array}{l}0 \cdot 8 \\
1 \cdot 0\end{array}$ & & $\begin{array}{l}1 \\
1\end{array}$ \\
\hline $2.50-56$ & , & Youths resting at far end of dormitory. & $0 \cdot 0$ & $0 \cdot 0$ & & 1 \\
\hline $\begin{array}{l}3.00-06 \\
3.08-14\end{array}$ & , & $\begin{array}{c}\text { Youths sweeping floor vigorously. } \\
\qquad, ",,\end{array}$ & $\begin{array}{l}4 \cdot 8 \\
5 \cdot 0\end{array}$ & $\begin{array}{l}* 150 \\
* 250\end{array}$ & & $\begin{array}{l}100 \\
100\end{array}$ \\
\hline $3.16-17 \frac{1}{2}$ & " & $", \quad "$, & & & $\mathrm{c} 2,000$ & \\
\hline $\begin{array}{l}3 \cdot 25-31 \\
3.35-36 \frac{1}{2}\end{array}$ & ", & Youths resting at far end of dormitory. & $\begin{array}{l}0.0 \\
0.0\end{array}$ & $\begin{array}{l}6 \cdot 6 \\
3 \cdot 5\end{array}$ & $\bar{c} 65$ & $\begin{array}{l}10 \\
10\end{array}$ \\
\hline $\begin{array}{l}3 \cdot 40-46 \\
3 \cdot 48-49 \frac{1}{2}\end{array}$ & ", & Youths shaking various blankets, pillows, and towels. & $7 \cdot 5$ & $* 120$ & $\overline{\mathrm{c}} 2,000$ & $\begin{array}{l}100 \\
100\end{array}$ \\
\hline $3.52-58$ & " & $\begin{array}{l}\text { Several pillows beaten, one at a time, } 3 \mathrm{ft} .(0.9 \mathrm{~m} \text {.) from } \\
\text { sampler. }\end{array}$ & $1 \cdot 8$ & 17 & & 100 \\
\hline $4.02-05$ & ", & Only 2 operators left in dormitory. & $0 \cdot 7$ & $1 \cdot 0$ & $\overline{\mathrm{c}} 130$ & 10 \\
\hline
\end{tabular}

* The three highest values for alpha streptococci were estimated approximately, a part only of each plate being counted. 
bacteria-carrying particles per cubic foot of air. The " dust readings" were roughly estimated from the number of dust particles observed on the surface of the culture plates with a plate microscope. They had no absolute significance, but indicate roughly the relative dust contents of the air at different times.

The results show that in the control period before " dust-raising," $\beta$ streptococci were not found in the air. Only a little infected dust was liberated into the air from the floor by the youths marching up and down the dormitory. Heavy air-infection with $\beta$ streptococci and other bacteria was, however, produced both as a result of vigorous sweeping of the floor and as a result of the shaking of blankets, pillows, and towels. The amount of air-infection was again greatly reduced within ten to fifteen minutes after the cessation of dust raising. The air content of visible dust particles appeared to parallel the amount of air-infection.

\section{Air-Infection with Dust from Clothing, Towels, and Handkerchiefs}

Observations were made of the bacterial content of the air of a small room $-14 \mathrm{ft} . \times 14 \mathrm{ft}$. $\times 10 \mathrm{ft}$. $(4.2 \mathrm{~m} . \times 4.2 \mathrm{~m} . \times 3 \mathrm{~m}$.) during the shaking of their jackets, towels, and handkerchiefs, by four "throat carriers" of $\beta$ streptococci. The room had, on the previous day, been emptied of furniture and hangings, and had been treated thoroughly with formalin. After the floor had been scrubbed with dettol, the room was left unoccupied until the time of the experiment. Because of these precautions, the production of air-infection by the raising of "room dust" was rendered highly improbable. To prevent the expulsion of dropletspray, the four "carriers" and the two operators were efficiently masked while present in the room during the experiment. "Dust raising" was effected as follows: (1) the carriers marched continually round the room, thus agitating their clothing gently; and (2) the carriers shook, in succession, their jackets, towels and handkerchiefs towards the centre of the room, where the air sampler was placed.

Air samples, each of $6 \mathrm{cu}$. ft., were taken before, during and after the "dust-raising." The findings are shown below as numbers of bacteria-carrying particles per cubic foot of air.

\begin{tabular}{|c|c|c|c|c|}
\hline \multicolumn{2}{|c|}{$\begin{array}{c}\text { Time of } \\
\text { Observation }\end{array}$} & Circumstances & $\begin{array}{l}\text { Beta } \\
\text { strep. }\end{array}$ & $\begin{array}{l}\text { Air } \\
\text { Dust }\end{array}$ \\
\hline $\begin{array}{l}5.26-32 p \\
5.33-39\end{array}$ & m. & Only the 2 operators present. & $\begin{array}{l}0 \cdot 3 \\
0 \cdot 5\end{array}$ & 1 \\
\hline $5 \cdot 40-46$ & , & $\begin{array}{l}\text { The } 4 \text { carriers enter and march } \\
\text { continuously round the sam- } \\
\text { pler. }\end{array}$ & 1.8 & 1 \\
\hline $\begin{array}{l}5.50-56 \\
6.00-06\end{array}$ & ,", & $\begin{array}{l}\text { The carriers shake towels, jackets, } \\
\text { and handkerchiefs. }\end{array}$ & $\begin{array}{l}* 150 \\
* 200\end{array}$ & $\begin{array}{l}100 \\
100\end{array}$ \\
\hline $\begin{array}{l}6.06 \frac{1}{2}-12 \frac{1}{2} \\
6.13-19 \\
6.20-25\end{array}$ & $\ddot{, "}$ & Only the 2 operators present. & $\begin{array}{r}* 250 \\
* 150 \\
100\end{array}$ & $\begin{array}{r}25 \\
10 \\
5\end{array}$ \\
\hline
\end{tabular}

* These high figures for beta streptococci were derived from colony counts which were only approximate as the zones of haemolysis were, in places, confluent.
Few $\beta$ streptococci were present in the air before the "carriers" entered. A small number were introduced into the air while the " carriers " marched round the room. Extremely large numbers of $\beta$ streptococci were found in the air during the shaking of jackets, towels and handkerchiefs. After this " dust raising," a high degree of air-infection persisted for at least twenty minutes.

\section{Discussion}

In a critical review, Bedford (1943) has stated "there may be various opinions as to whether direct droplet-infection or airborne infection is the more important mode of transmission of respiratory disease, but there seems to be no real knowledge as to their relative importance." The demonstration by Wells (1934 and 1935), by Jennison (1942), and by Bourdillon, Lidwell, and Lovelock (1942) that large numbers of droplets, which are small enough to remain airborne as droplet-nuclei, may be expelled in sneezing, coughing, and speaking, suggested that air-infection of considerable magnitude may be produced directly by droplet-spray. On the other hand, Bloomfield and Felty (1924) and Hare (1940) found that, in the case of haemolytic streptococcal throat infections, only a small proportion of the droplets expelled in speaking, coughing, and sneezing, contained any of the pathogenic organisms. Hare, moreover, found that such haemolytic streptococci as were expelled were confined to the large droplets, and that none were present in the small droplets which remained airborne as droplet-nuclei. He suggested that airinfection was produced by the liberation into the air of infected dust particles from objects which had been soiled with the large infected droplets.

The importance of infected dust in the spread of infection has been emphasized by the findings of many investigators; Str. pyogenes have been found in very large numbers on the clothing and bedclothes of infected persons, and in the dust of the floor and furnishings of the rooms occupied by these persons; great increases in the number of Str. pyogenes in the air of wards occupied by infected persons have been found to occur during bed-making, sweeping, the toilet of patients, and the serving of meals (White, 1936; Brown and Allison, 1937; van den Ende, Lush and Edward, 1940; Thomas and van den Ende, 1941; Cruickshank, 1941; Hare, 1941; Wright, Cruickshank and Gunn, 1944; Hamburger, Puck, Hamburger, and Johnson, 1944 and 1945).

The demonstration that such air-infection is greatly reduced by dust-suppressive measures, such as the oiling of floors and bedding, has furnished further proof of the important part played by " dustraising " in the production of air-infection (van den Ende, Lush and Edward, 1940; Andrewes, 1940; Thomas and van den Ende, 1941; Thomas, 1941). Feasby and Bynoe (1944), in circumstances similar to those recorded in the present investigation, were able to show that dust control, as apart from overcrowding, was a factor which materially influenced 
the infection rate. Wright, Cruickshank and Gunn (1944) have also found dust-suppressive measures to reduce the incidence of streptococcal crossinfections in hospital wards.

The findings obtained in the present investigation accord with the view that air-infection with Str. pyogenes is produced mainly by the liberation into the air of infected dust from the clothing, towels, handkerchiefs, bedclothes, and environmental furnishings of infected persons, and that direct introduction into the air of infected droplet-nuclei does not occur to any great extent.

\section{Summary}

Observations were made of the amount of airinfection with Str. pyogenes (1) in the immediate vicinity of four "throat carriers" who, while playing a game of cards, were talking, laughing, and coughing frequently and vigorously; (2) in a dormitory which was normally occupied by " throat carriers" (but not at the time of observation), during sweeping and the shaking of bedclothes, and (3) in a room where the jackets, towels, and handkerchiefs of four " throat carriers " were vigorously shaken.

The amount of air-infection was small in the first case (on an average 0.8 Str. pyogenes-carrying particles per cubic foot of air), considerable in the second case (on an average about $5 \mathrm{Str}$. pyogenescarrying particles per cubic foot of air), and very great in the third case (on an average, about $200 \mathrm{Str}$. pvogenes-carrying particles per cubic foot of air).

We wish to acknowledge our indebtedness to ViceAdmiral Sir Sheldon F. Dudley, Medical Director General, for permission to publish this report.

\section{REFERENCES}

Andrewes, C. H. (1940), Lancet, 11, 770.

Bedford, T. (1943). Bull. Hyg., 18, 91.

Bloomfield. A. L.. and Felty, A. R. (1924). John Hopk. Hosp. Bull., 34,115

Bourdillon, R. B.. Lidwell, O. M., and Lovelock. J. E. (1942). Brit. med. J., 1, 42 .

- , and Thomas, J. C. (1941). J. Hyg., 41. 197.

Brown, W. A.. and Allison, V. D. (1937). Ibid., 37, 1.

Cruickshank, R. (1941). Lancet, 1, 493 .

Feasby, W. R.. and Bynoe, E. T. (1944). War Med.. Chicago, 5. 107.

Hamburger, M.. Puck, T. T., Hamburger, V. G., and Johnson, M. A. (1944) J. infect. Dis 75, 79 .

Hare. R. (1940). Canad. publ. Hith. J., 31, 539

Hare. R. (1940). Canad. publ

Jennison, M. W. (1942). In Aerobiology, Amer. Assoc. Adv. Sci. pub. No. 17. Washington, D.C., p. 106

Thomas, J. C. (1941). Lancet, 2, 123

-, and van den Ende, M. (1941). Brit. med. J.. 1. 953.

an den Ende M., Lush, D., and Edward D. G. ff. (1940). Lancet, 2, 133.

Wells, W. F. (1934). Amer. J. Hyg., 20, 611.

(1936). J. Ind. Hyg. Toxicol., 17, 253.

White, E. (1936). Lancet, 1, 941. 